\title{
STUDY OF BUILDING MASS ARRANGEMENTS IN TAHFIDZ PRENEUR ISLAMIC BOARDING SCHOOL AREA QUR'AN CENDEKIA
}

\author{
Andiyan, Siti Maryam Fauziah \\ Architecture Study Program, Faculty of Science and Engineering, Universitas Faletehan \\ andiyanarch@gmail.com
}

Received: 04 March 2021; Revised: 06 June 2021; Accepted: 28 August 2021

DOI: http://dx.doi.org/10.37905/aksara.7.3.843-850.2021

\begin{abstract}
Abstrak
Pesantren adalah suatu lembaga pendidikan Islam untuk mempelajari, memahami, mendalami, menghayati, dan mengamalkan ajaran Islam dengan sistem asrama. Tujuan Penelitain memperhatikan Lingkungan dan sosial pesantren harus menjadi tempat yang nyaman untuk para santri untuk belajar karena semua kegiatan di lakukan di dalam pesantren. Penelitian ini menggunakan metode kualitatif dengan mendapatkan pemahaman yang lebih mendalam mengenai objek yang diteliti.Hasil penelitian ini dimana Penerapan konsep Arsitektur Ekologi pada Lingkungan dan social Pesantren Tahfidz Preneur Kampoeng Qur'an Cendekia dapat di lihat dari pengunaan bahan pada bangunan asrama para santri yang menggunakan kayu dan bamboo sebagai bahan utama, tatanan bangunan dengan memaksimalkan penggunaan kontur, dan juga orientasi bangunan.Kesimpulan Pesantren Tahfidz Preneur Kampoeng Qur'an Cendekia merupakan salah satu pesantren di daerah Parompong Bandung Barat dengan penerapan konsep Arsitektur Ekologi.
\end{abstract}

Kata Kunci : Pesantren, Ekologi, Iklim, Orientasi, Lingkungan, Arsitektur

\section{Abstract}

A boarding school is an Islamic educational institution to study, understand, deepen, appreciate, and practice Islamic teachings with a boarding system. This research aims to pay attention to the environment and social conditions of the boarding school to be a comfortable place for students to study because all activities are carried out in the Boarding school. This study uses a qualitative method by gaining a deeper understanding of the object under study. The results of this study are the application of the concept of Ecological Architecture to the environment and society at the Tahfidz Preneur Kampoeng Qur'an Cendekia Islamic Boarding School, which can be seen from the use of materials in the boarding houses of the students using wood and bamboo as the primary material, the structure of the building by maximizing the use of contours, and also the orientation of the building. Conclusion The Tahfidz Preneur Kampoeng Qur'an Cendekia Islamic Boarding School is one of the Islamic boarding schools in the Parompong area of West Bandung with Ecological Architecture.

Keywords: Islamic Boarding School, Ecology, Climate, Orientation, Environment, Architecture

\section{INTRODUCTION}

Boarding school is a traditional educational institution in Islam in Indonesia to understand, appreciate, and practice the teachings of Islam (tafaqquh fiddin) by emphasizing the importance of Islamic moral as a guide for everyday social life (Mastuhu, 
1994). Boarding school is also an education system that implements a boarding system. Islamic boarding schools have developed starting with traditional pesantren which only teach about the Islamic religion which only requires mosques and dormitories. However, along with the development of the era, the Boarding school developed both in terms of curriculum and vision and mission where Boarding school not only learn about the religion of Islam but also add teaching and learning activities in general or public schools and are now increasingly developing with the emergence of modern Islamic boarding schools (Nisa, 2017). With the development of Islamic boarding schools, the need for space and the design of Islamic boarding schools have developed, initially focused only on mosque buildings. However, nowadays, pesantren are experiencing design developments and the need for quite a lot of space to support the activities of modern boarding schools (Nuraeni, 2012). In addition to the development of spatial design, mass arrangement and architectural formations also developed. One of the architectural concepts that are of particular interest is the concept of ecological architecture. This concept is used in the arrangement and selection of building area material and also determine the orientation of the building. Islamic boarding schools with the concept of ecological architecture are also called eco- boarding schools (Christin, Naila Woro Martini \& Bagus Pribadi, 2016).

The notion of Ecological Architecture itself is the harmony between the building and its natural surroundings. These elements work in harmony to produce comfort, security, beauty and interest(Irwan \& Hasanbahri, 2012). The concept of Architectural Ecology is a blend of environmental science and architectural science that is oriented towards a development model by taking into account the balance of the natural and artificial environments (Arfan, Ersina, \& Irham, 2016). The focus of the study is that Tahfidz Preuneur Islamic Boarding School is one of the boarding schools in the Parompong area of West Bandung with the application of the concept of Ecological Architecture. Tahfidz Preuneur Islamic Boarding School applies the concept of ecological architecture with consideration of the potential contained in the site and the surrounding environment, such as maximizing contoured land, using materials and also making optimal use of the arrangement of building mass structures that minimize damage to the topography of the soil, optimizing view potential on the tread.

Previous researchers (Digna, Nur Rahmawati, \& Yayi Arsandrie, 2016) Previous research had been conducted at the boarding schools which later found many problems in terms of architecture, especially regarding the comfort of living in the santriwati's bedroom, which was caused by in optimal openings and the structure of the building period that was too coincided. Then this problem can be solved with the concept of architectural ecology. As well as further researchers (Adam \& Rinnarsuri, 2020), The concept of the appearance of the Tahfidz Al-Qur'an Islamic Boarding School building considers the standards for the overall appearance of the building according to educational standards that are adapted to applying ecological architectural concepts such as the use of the concept of cross ventilation, the application of double glass, and solar panels. In the outdoor space there are many gardens, many parks so that students can memorize in an open environment with a calm atmosphere so that it can help in the process of memorizing the students. Within the boarding schools area there are also gardens to produce the food needs of students and implement systems for waste water management and rainwater management. The importance of this research, attention to the environment, and so s all 
schools should be a comfortable place for the students to learn because of all the activities undertaken in the boarding schools (Azhima, Wisnu Setiawan, \& Arch, 2019). For example, one of the Islamic boarding schools in the Parompong area of West Bandung, namely Tahfidz Preuneur Islamic Boarding School, is designed using Ecological Architecture (EcoArchitecture). Ecological Architecture is a design solution in architecture with an ecological orientation and the interaction between living things and their environment (sunlight, climate, geology, including living things in their habitat) that is environmentally friendly.

The research aims to pay attention to the Environment and Social Environment of the pesantren, which must be a comfortable place for students to learn because all activities are carried out in the boarding schools.

\section{RESEARCH METHODS}

This study used a qualitative method by gaining a deeper understanding of the object under study (Sugiyono, 2012). In this study, the researcher divided the research into three stages, the Research Preparation Stage, the Research Implementation Stage, and the final stage (Sugiyono, 2005). At the research preparation stage, the researcher makes observations, identifies problems, determines the problem formulation, and collects literature studies as a reference. In the next stage of research, the researcher conducts site surveys, documentation, and analysis of research variables, and the final stage is collecting data, processing data, analyze and draw conclusions (Moleong, 2007). This research is expected to reference his research and can be developed again to a broader scale. Because research on cultural heritage buildings is still quite extensive and there are not many people who take this theme as their research theme (Andiyan, Nurrisman, 2021).

\section{RESULTS AND DISCUSSION}

\section{Ecological Architectural Design Principles}

- Solution Grows from Place

By having two direct access, this boarding school is very open to interaction social on the surrounding communities and building materials from bamboo to develop economy Public about because it is not far from the school are artisans bamboo (Ernst, 2002).

\section{- Ecological Accounting Informs Design}

Reducing the pavement on the site with more softscape or water infiltration reduces the impact of water inundation (Hamdi, 2016).

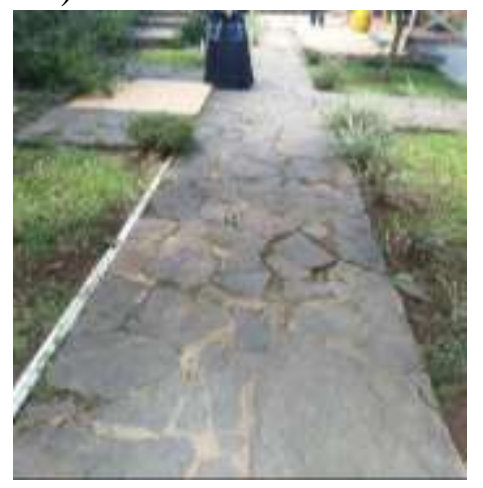

Figure 1 Pedestrian pavement

Source: Personal documentation 


\section{- Design with Nature}

Protecting the surrounding environment by maintaining the vegetation in the site is an effort to keep it natural (Reiza \& Wibowo, 2017).

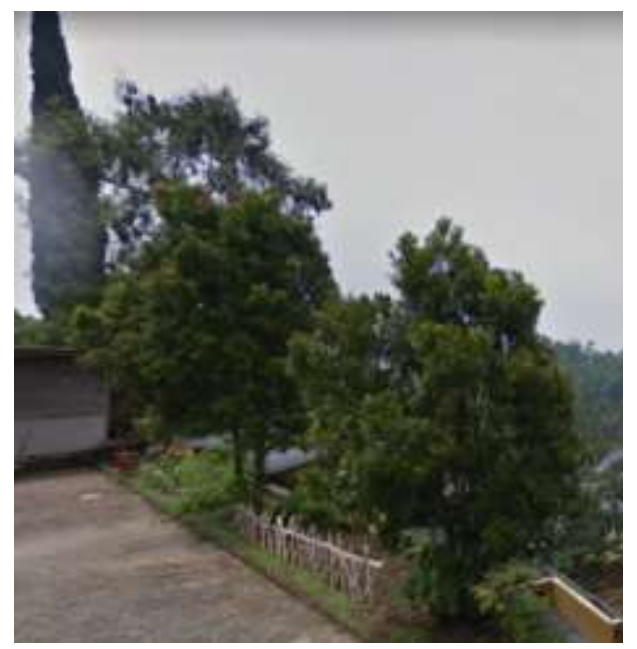

Figure 2 Vegetation

Source: Personal documentation

\section{- Make Nature Visible}

The processing of organic waste into manure at the Preneur Kampoeng Qur'an Cendekia Islamic Boarding School is to reduce waste (Prianto, Sujono, \& Dwiyanto, 2019).

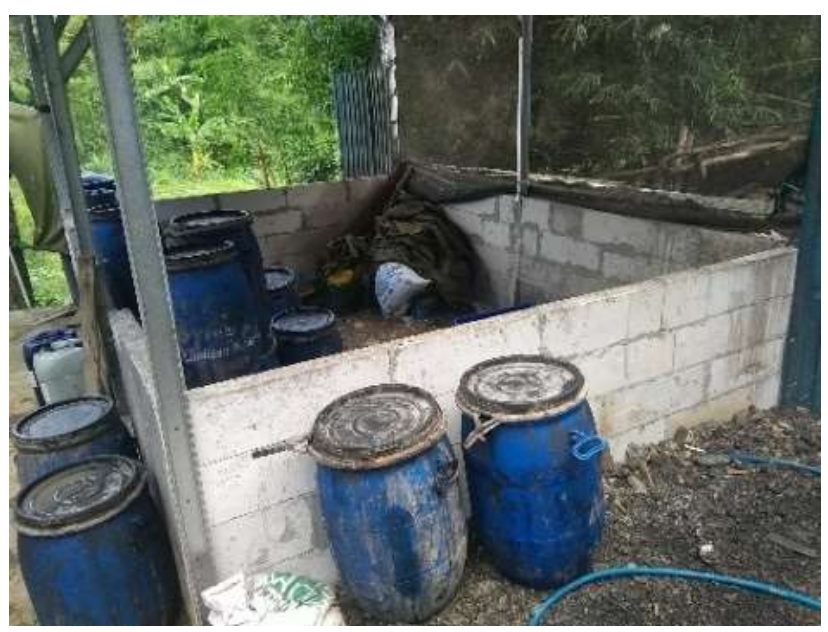

Figure 3 Processing of organic waste in a barrel Source: Personal documentation

\section{Aspects of Architectural Ecology}

- Design Ecology Architect

1. Integration of local ecological conditions, climate macro and micro: For Region located in tropical climates with high rainfall drainage system needs attention so that 
rainwater quickly flows and does not stagnate because this Region lacks a drainage system.

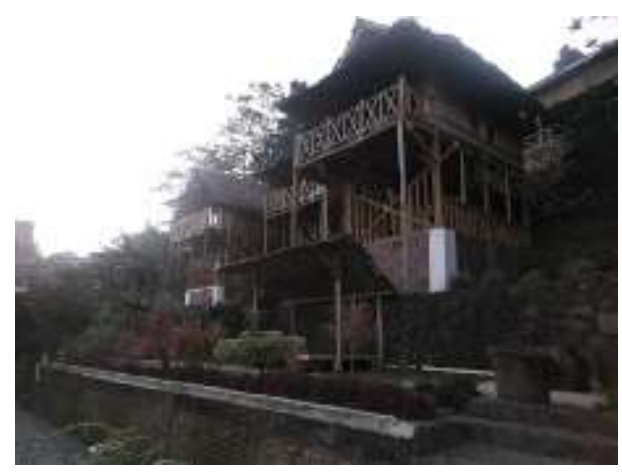

Figure 4 Drainage system in the area Source: Personal documentation

2. Conditions tread: tread condition at Tahfidz Preuneur Islamic Boarding School is contoured tread with the Natural Environment.

3. Climate responsive design concepts and systems; With gable roofs and joglo roofs on buildings that allow rainwater to fall quickly, this is one solution for buildings in tropical climates.

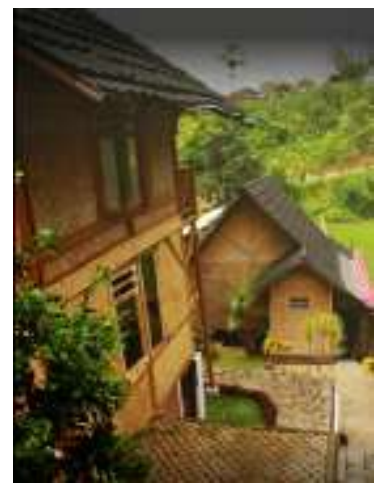

Gambar 5 Gable

Source: Tahfidz Preuneur Islamic Boarding School Archives

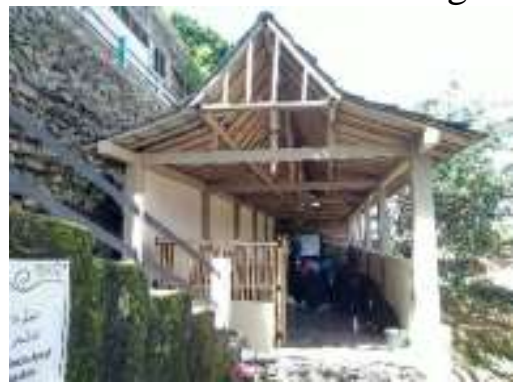

Figure 6 The roof of the joglo Archives

Source: Documentation 
4. Low Energy Use; With the number of openings then reduce the use of lights and save energy.

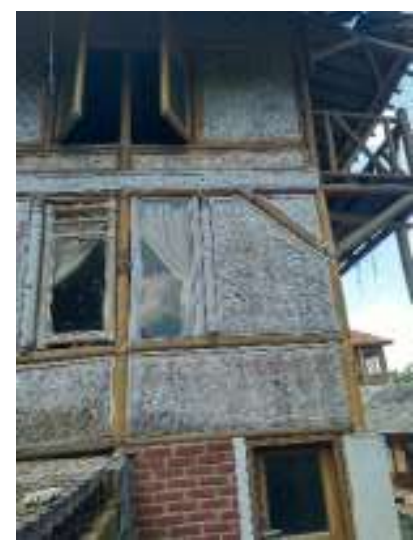

Figure 7 Openings in buildings

Source: Personal documentation

\section{- Structural and construction aspects}

Aspects of the structure used in this area are sengkeden houses on the slopes $>10 \%$ and split level also uses gabion retaining walls.

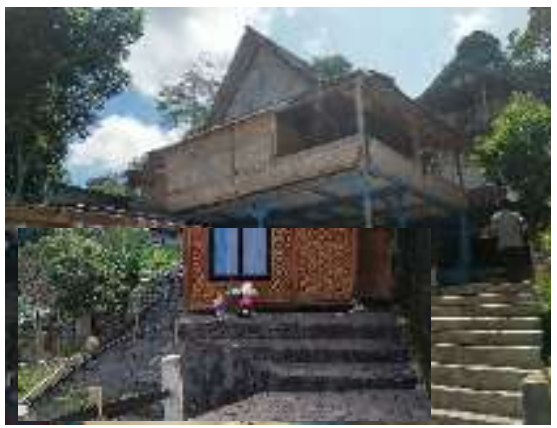

Figure 8 retaining wall of gabions in a building

Source: Documentation

\section{- Aspects of building materials}

The use of building materials at the Tahfidz Preuneur Islamic Boarding School in Kampoeng Quran Cendekia partially uses bamboo as basic materials which are easy to find and renew. Building materials or materials used in this area are as follows (Ibrahim, 2016) :

- Bamboo: $60 \%$

- Natural stone: $20 \%$

- Other ingredients: $20 \%$

5. Mass Order

The mass order at the Tahfidz Preuneur Islamic Boarding School Kampoeng Quran Cendekia uses a mass arrangement in a cluster configuration and a grid form where the percentage is $50 \%$ cluster configuration and 50\% grid form (Ching, 2008). 


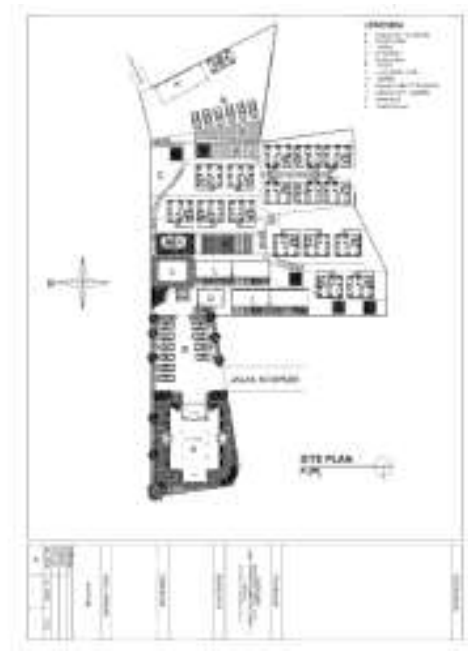

Figure 9 Tahfidz Preuneur Islamic Boarding School Siteplan Kampoeng Qu'ran Scholar Source: Personal documentation

\section{CONCLUSIONS}

Preneur Kampoeng Qur'an Cendekia Islamic Boarding Schoo is one of the pesantren in the Parompong area of West Bandung with the application of Ecological Architecture. Preneur Kampoeng Qur'an Cendekia Islamic Boarding Schoo applies the concept of ecological architecture by considering the potential contained in the site and the surrounding environment, such as maximizing contoured land, using materials and also making optimal use of it by structuring the mass structure of the building which minimizes damage to the topography of the land, optimizing the potential view on the site. . Based on the results of observations it can be concluded that:

1. The mass structure in the Tahfidz Preuneur Kampoeng Quran Cendekia Islamic Boarding School area uses a cluster configuration mass structure, and also the grid shape can be seen using the same mass structure but lack of ramp circulation in the Boarding School area.

2. The ecology of the Region Tahfidz Preuneur Kampoeng Quran Cendekia Islamic Boarding School uses an ecological architecture that can be seen from the design emphasis, the principle of design and architecture aspects ecological aspects.

\section{Suggestion}

1. Based on the results of observations and research, it can be concluded that the researcher provides the following suggestions;

2. Maintenance in Tahfidz Preuneur Kampoeng Quran Cendekia Islamic Boarding School needs to be improved again, especially in the waste management section, so that it does not look slum.

3. Maintenance of buildings that use natural materials must be maintained so that they are maintained and sturdy.

4. Added a ramp for pedestrian access to make it friendly for people with disabilities.

5. I am adding drainage channels to make it easier for water to drain so that there are no many puddles. 


\section{REFERENCES}

Adam, Muhammad, \& Rinnarsuri, Dwi. (2020). Penerapan Konsep Arsitektur Ekologi Pada Pesantren Tahfizh Al-Qur'an Di Kota Kendari. GARIS Jurnal Mahasiswa Jurusan Arsitektur, 5(2).

Andiyan,Nurrisman, Okki. (2021). Implementation of the New Function of the Sarinah Braga Building ( Hotel De Braga By Artotel ). Solid State Technology, (7). Retrieved from https://www.solidstatetechnology.us/index.php/JSST/article/view/10569

Arfan, Taufik, Ersina, Sriany, \& Irham, Irham. (2016). Redesain Kawasan Pondok Pesantren Sultan Hasanuddin Di Kabupaten Gowa Sulawesi Selatan. Nature: National Academic Journal of Architecture, 3(1), 81-90.

Azhima, Farah Fauzan, Wisnu Setiawan, S. T., \& Arch, M. (2019). Redesain Pondok Pesantren Islamic Centre Bin Baz Yogyakarta dengan Pendekatan Konsep Ekologis. Universitas Muhammadiyah Surakarta.

Charistin, Naila Woro Murtini, Titien, \& Bagus Pribadi, Septana. (2016). SMP Dan SMA Boarding Al-Adzkar Di Tangerang Selatan. Fakultas Teknik Undip.

Ching, DK. (2008). Architecture: Space \& Order. Bandung: Erlangga.

Digna, Ifannisa, Nur Rahmawati, S., \& Yayi Arsandrie, S. T. (2016). Redesain Pondok Putri Pesantren Islam Al Mukmin Ngruki Sukoharjo (Dengan Pendekatan Ekologi Arsitektur). Universitas Muhammadyah Surakarta.

Ernst, Neurfert. (2002). Data Arsitek jilid 2. In Erlangga (Vol. 4). Retrieved from http://marefateadyan.nashriyat.ir/node/150

Hamdi, Nadiyah. (2016). Perancangan Eco-Islamic Boarding School Di Sokaraja. Universitas Gadjah Mada.

Ibrahim, Muhammad. (2016). Perancangan wisata edukasi olahraga Islam (berkuda, berenang dan memanah) di Kota Wisata Batu: Tema arsitektur ekologi. Universitas Islam Negeri Maulana Malik Ibrahim.

Irwan, Siti Nurul Rofiqo, \& Hasanbahri, Soewarno. (2012). Fungsi Vegetasi Pada Ruang Hijau Dan Hutan Kota Untuk Pengembangan Lanskap Eco Pesantren Studi Kasus: Pondok Pesantren Nurul Jadid Probolinggo. Makalah Prosiding Seminar UMS. Universitas Muhammdiyah Surakarta.

Mastuhu. (1994). Dinamika Sistem Pendidikan Pesantren. jakarta: INIS XX.

Moleong, Lexy J. (2007). Metodologi Penelitian Kualitatif. Yogyakarta: Gadjah Mada University Press.

Nisa, Lutfia Brilian. (2017). Eco-Pesantren Tahfidzul Qur'an Di Boyolali Dengan Pendekatan Arsitektur Ekologi.

Nuraeni, Effih. (2012). Konsep Arsitektur Ekologi pada Pondok Pesantren Al-Amien Putra di Kabupaten Sumenep. Universitas Brawijaya.

Prianto, Eddy, Sujono, Bambang, \& Dwiyanto, Agung. (2019). Aplikasi Rancangan Green Pesantren Di Semarang. Jurnal Riptek, 11(1), 81-98.

Reiza, Ikhwan, \& Wibowo, Heru. (2017). Penerapan Vegetasi Pada Bangunan Studi Kasus: Desain Model Asrama Eco-Pesantren. Jurnal Arsitektur ARCADE, 1(2), 5256.

Sugiyono. (2012). Metode Penelitian Kuantitatif Kualitatif dan R\&B. Bandung: CV. Alfabeta.

Tiaratanto, Excya,Affandi,Kemal, Andiyan. (2021). Bangunan konvensi dan eksibisi bandung. Jurnal Arsitektur Archicentre, (126), 1-13. 